\title{
Kinas fremstormen og Vestens fremtid
}

G. John Ikenberry

Kina kan måske overhale USA, men det er mindre sandsynligt, at det kan overhale den vestlige verdensorden. Den kapitalistiske og demokratiske verden er en magtfaktor til fordel for den bestående verdensorden, og hvis Kina vil udfordre den, har det en stor opgave foran sig

Kina indtagelse af en førende position vil uden tvivl blive et af det 21 . århundredes store dramaer. Kinas enestående økonomiske vækst og aktive diplomati er allerede godt $\mathrm{i}$ gang med at omforme Østasien, og i de kommende årtier vil den kinesiske magt og indflydelse tage endnu mere til. Præcis hvordan dette drama vil udspille sig er imidlertid et åbent spørgsmål. Vil Kina omstyrte den bestående verdensorden eller blive en del af den? Og hvad (om noget) kan USA gøre for at bevare sin position, mens Kina stormer frem?

Der er iagttagere, der er overbevist om, at den amerikanske æra er ved at være til ende og den vestvendte verdensorden ved at blive erstat- tet af en stadigt mere østligt orienteret orden. Historikeren Niall Ferguson har skrevet, at det blodige 20. århundrede blev 'Vestens fald', og at en global 'nyorientering' mod øst tog sin begyndelse.

Folk fra den realistiske skole siger endvidere, at efterhånden som Kina bliver mere magtfuld, og USA's position undermineres, vil der med al sandsynlighed ske to ting: Kina vil forsøge at bruge sin stigende indflydelse til at omforme det internationale systems regler og institutioner i egen favør, og andre stater i systemet (særligt den tidligere enehersker) vil give sig til at betragte Kina som en stadigt større sikkerhedsrisiko.

Resultatet (forudsiger de) vil være 
spændinger, mistro og konflikt: typiske træk ved magtskifter. I dette scenario vil dramaet om det fremstormende Kina som hovedpersoner have et stadig mere magtfuldt Kina og et USA på vej ned. De vil være fastlåst i en vældig batalje om reglerne og lederskabet i det internationale system. Og eftersom verdens største land ikke er opstået inden for, men uden for efterkrigstidens etablerede verdensorden, vil dramaet ende med Kinas overherredømme og frembruddet af en asiatisk centreret verdensorden.

\section{Ikke uundgåeligt}

Det scenario er imidlertid ikke uundgåeligt. Kinas opkomst behøver ikke udløse et voldsomt og smertefuldt magtskifte fra én enehersker til en anden. Magtskiftet fra USA til Kina kan blive meget forskelligt fra fortidens magtskifter, fordi Kina er oppe imod en verdensorden, der er fundamentalt forskellig fra de ordner, som fremstormende stater i fortiden var oppe imod.

Kina er ikke blot oppe imod USA, men imod hele det vestligt centrerede system. Og det system er åbent, samkørt og gennemreguleret og har et omfattende og rodfæestet politisk fundament. Samtidig har den atomare revolution gjort krig mellem stormagter usandsynlig og dermed udryddet det væsentligste våben, som fremstormende stater før i tiden har benyttet sig af til at omstyrte verdensordner, der blev forsvaret af eneherskende stater i forfald. Nutidens vestlige verdensorden er kort sagt svær at omstyrte og nem at tilslutte sig.

Denne usædvanligt holdbare og omfattende verdensorden er i sig selv et produkt af fremsynet amerikansk lederskab. Efter Anden Verdenskrig etablerede USA ikke ganske enkelt sig selv som den førende verdensmagt. USA førte an i skabelsen af fælles institutioner, som ikke alene opfordrede til medlemskab verden over, men også førte demokratier og samfund med frie markeder nærmere sammen. USA opbyggede en verdensorden, der lettede deltagelsen og samkøringen af såvel etablerede stormagter som nyligt uafhængige stater. (Man glemmer ofte, at denne efterkrigsorden i rigt mål blev skåret til, så den kunne indoptage de slagne Aksemagter og de trængte Allierede i et samlet internationalt system.)

I dag kan Kina opnå fuld adgang til dette system og blomstre inden for det. Og hvis Kina vælger at gøre dette, vil Kina storme frem, uden at den vestlige verdensorden vil afgå ved døden af den grund - forudsat at denne orden bliver håndteret ordentligt.

USA bør i konfrontationen med det fremstormende Kina huske på, at det amerikanske lederskab af den vestlige verdensorden gør det muligt for USA at skabe det miljø, inden for hvilket Kina vil træffe afg $\varnothing$ - 
rende strategiske valg. Hvis USA ønsker at bevare sit lederskab, er den amerikanske regering nødt til at styrke de regler og institutioner, som underbygger og afstiver denne verdensorden, og dermed gøre den endnu lettere at tilslutte sig og sværere at omstyrte.

USA's overordnede strategi bør opbygges omkring mottoet om, at vejen til Østen går gennem Vesten. USA må slå så dybe rødder som muligt i den vestlige verdensorden og give Kina bedre grunde til at gå med i den end til at sætte sig op imod den. Det vil øge chancerne for, at systemet vil overleve, selv efter at den amerikanske magt er blevet svækket.

USA's unipolære stund vil uundgåeligt få en ende. Hvis den afgørende kamp i det 21. århundrede står mellem Kina og USA, er det Kina, som står stærkest. Hvis den afgørende kamp derimod står mellem Kina og et vestligt system med fornyet livskraft, er det Vesten, der vil gå af med sejren.

\section{Overgangsangst}

Kina er godt på vej til at blive en drabelig verdensmagt. Landets økonomi er firdoblet siden indførelsen af markedsreformer sidst i 1970'erne og vil ifølge nogle beregninger fordobles yderligere i løbet af det næste tiår. Kina er blevet et af verdens største produktionscentre og forbruger omkring en tredjedel af verdens jern-, stål- og kulforsynin- ger. Landet har akkumuleret massive reserver af fremmed valuta: ved udgangen af 2006 reserver til en værdi af mere end 1.000 milliarder dollar. Kinas militærbudget er øget med mere end 18 procent om året, når man korrigerer for inflation, $\mathrm{og}$ landets diplomati har udvidet sin rækkevidde ikke blot i Asien, men også i Afrika, Latinamerika og Mellemøsten. Mens Sovjetunionen alene konkurrerede militært med USA, stormer Kina frem som både en militær og en økonomisk rival og indvarsler en dybtgående forandring i fordelingen af den globale magt.

Magtskifter er et tilbagevendende problem i internationale relationer. Forskere som Paul Kennedy og Robert Gilpin har beskrevet, hvordan international politik har været præget af en række magtfulde stater, der én efter én har organiseret det internationale system. En magtfuld stat kan oprette og gennemtvinge regler og institutioner i en stabil verdensorden, hvori den kan forfølge sine interesser og garantere sin egen sikkerhed.

Men intet varer evigt: Forandringer over tid i fordelingen af magten lader nye udfordrerstater vokse frem, som udløser en kamp om betingelserne i den givne verdensorden. Fremstormende stater ønsker at omsætte deres nyvundne magt til større indflydelse i det globale system: at genskabe reglerne og institutionerne i overensstemmelse med 
deres egne interesser.

Stater på vej ned frygter på deres side tabet af kontrol og gør sig bekymringer om, hvad deres svækkede position betyder for deres sikkerhed.

Disse overgangstider er fulde af farer. Når en stat sidder i en herskerposition i det internationale system, føler hverken den eller svagere stater nogen tilskyndelse til at ændre den bestående verdensorden. Men når en udfordrerstat opnår stadig større magt, og den herskende stats magt mindskes, opstår der en strategisk rivalitet og sandsynligvis konflikt - som kan munde ud i krig.

Faren i forbindelse med magtskifter fremstår med dramatisk tydelighed i situationen, som den var i Tyskland i slutningen af det 19. århundrede. I 1870 var Storbritannien økonomisk tre gange stærkere end Tyskland og havde tillige en betydelig militær overmagt. I 1903 havde Tyskland overhalet Storbritannien såvel økonomisk som militært.

I takt med Tysklands daværende forening og vækst voksede også den tyske utilfredshed og de tyske krav; og efterhånden som landet blev mere magtfuldt, fremstod det i stigende grad som en trussel mod andre stormagter i Europa, hvorfor en sikkerhedskonkurrence opstod. I den strategiske omgruppering, der fulgte, slog tidligere fjender som Frankrig, Rusland og Storbritannien pjalterne sammen for at konfrontere det fremstormende Tyskland. Re- sultatet var en europæisk krig.

Mange iagttagere ser den samme dynamik på vej frem i forholdet mellem USA og Kina. "Hvis Kina fortsætter sin imponerende økonomiske vækst i de næste par tiår," har forskeren John Mearsheimer fra den realistiske skole skrevet, "vil USA og Kina med al sandsynlighed indgå i en hård kappestrid på sikkerheden med betydelig risiko for krig."

\section{Forskellige former for magtskift}

Ikke alle magtskifter fører dog til krig eller omstyrter den gamle verdensorden. I de første årtier af det 20. århundrede afgav Storbritannien magt til USA uden nogen større konflikt eller sågar noget brud i forholdet. Fra sidst i 1940'erne og frem til starten af 1990'erne voksede Japans økonomi fra at være fem procent af USA's bruttonationalprodukt til at være over 60 procent af det amerikanske BNP; alligevel udfordrede Japan på intet tidspunkt den eksisterende verdensorden.

Magtskifter kan tydeligvis antage forskellige former. Nogle stater har valgt at tilpasse sig den bestående orden trods dramatisk vækst i deres egen økonomiske og geopolitiske magt. Andre er stormet frem og har forsøgt at udfordre ordnen. Nogle magtskifter har ført til den gamle ordens nedbrud og etableringen af et nyt internationalt hierarki. Andre magtskifter har alene medført begrænsede tilpasninger i det regiona- 
le og globale system.

En række forskellige forhold afgør måden, hvorpå magtskifter udfolder sig. Afgørende er styrets natur i den fremstormende stat og graden af utilfredshed med den gamle verdensorden. I slutningen af det 19. århundrede var det liberale USA på et fuldt verdenshavs afstand af Europa således bedre i stand til at tage den britisk centrerede verdensorden til sig, end Tyskland var. Endnu mere afgørende er imidlertid karakteren af selve verdensordnen for det er systemets karakter, der former den fremstormende stats valg mellem at udfordre den eksisterende verdensorden eller at indordne sig i den.

\section{Åben verdensorden}

Efterkrigstidens vestlige verdensorden er historisk enestående. Enhver verdensorden centreret omkring en dominerende stat er baseret på en blanding af tvang og villighed; men den amerikansk ledede verdensorden adskiller sig derved, at den har været mere liberal end imperial - og usædvanligt tilgængelig, legitim og holdbar.

Denne verdensordens regler og institutioner har rødder i (og afstives derfor af) de verdensomspændende demokratiske og kapitalistiske kræfters udfoldelse. Den er omfattende og har en bred vifte af deltagere og parthavere, der bare bliver flere og flere. Den er i stand til at generere forrygende økonomisk vækst og magt, samtidig med at den signalerer beherskelse - hvilket alt sammen gør den svær at omstyrte og nem at tilslutte sig.

Det var den udtrykkelige hensigt hos de bygmestre, der i 1940'erne skabte den vestlige verdensorden, at skabe en orden, der var imødekommende og omfattende. Indtil den Kolde Krig splittede verden op i konkurrerende lejre, stræbte den amerikanske præsident Franklin Roosevelt efter at oprette et verdensomfattende system ledet af samarbejdende stormagter. Et system, der kunne genopbygge det krigshærgede Europa, indoptage de besejrede stater og etablere mekanismer til sikkerhedssamarbejde og omfattende økonomisk vækst.

Faktisk var det Roosevelt, der overtrumfede britiske Winston Churchill og fik igennem, at Kina skulle optages som permanent medlem i FN's sikkerhedsråd.

Australiens daværende ambassadør i USA skrev i sin dagbog under krigen, efter at have mødtes med Roosevelt for første gang: "Han sag$\mathrm{de}$, at han havde talrige diskussioner med Winston om Kina, og at Winston forekom ham at være 40 år bagud i sit forhold til Kina: Winston omtalte konstant kineserne som 'skævøjer' og 'kinamænd', og Roosevelt mente, at det var en meget farlig holdning at have. Roosevelt ville gerne have Kina som ven, fordi Kina om 40 eller 50 år nemt kunne blive 
en meget magtfuld militærnation."

I løbet af det følgende halve århundrede gjorde USA god brug af det system af regler og institutioner, som landet selv havde opbygget. Vesttyskland blev knyttet til sine demokratiske naboer i Vest gennem den Europæiske Kul- og Stålunion (og senere det Europæiske Fællesskab) og til USA gennem Atlantpagten. Japan blev knyttet til USA gennem et alliancepartnerskab og stadigt tættere økonomiske bånd.

Bretton Woods-konferencen i 1944 fastlagde de valuta- og handelsregler, som muliggjorde åbningen af verdensøkonomien og dens efterfølgende opblomstring - en forbløffende bedrift, når man betænker krigens hærgen og stormagternes modstridende interesser. Yderligere aftaler mellem USA, Vesteuropa og Japan befæstede verdensøkonomiens åbne og mangesidige karakter i efterkrigstiden.

Efter den Kolde Krigs udbrud blev de slagne Aksemagter yderligere indpasset i den vestlige verdensorden af Marshallplanen i Europa og sikkerhedspagten mellem USA og Japan i 1951.

\section{System med succes}

I den Kolde Krigs sidste dage viste dette system sig endnu engang overmåde succesrigt.

Under Sovjetunionens fald tilbød den vestlige verdensorden et sæt regler og institutioner, der bibragte de sovjetiske ledere såvel forsikringer som adgangsruter, hvorved man effektivt opmuntrede dem til at blive en del af systemet. Det kollektive lederskab af verdensordnen sikrede tillige indoptagelsen af Sovjetunionen. Mens den amerikanske Reagan-regering lagde sig fast på en hård linje over for Moskva, søgte europæerne afspænding og gik aftalevejen.

For hvert af strammernes skub var der et modererende træk, som tillod Mikhail Gorbatjov at gennemføre højst risikable reformer. Umiddelbart forud for Tysklands genforening bidrog det faktum, at landet ville blive indlejret $\mathrm{i}$ institutioner $\mathrm{i}$ Europa og henover Atlanterhavet frem for at blive en uafhængig stormagt til at forsikre Gorbatjov om, at hverken de tyske eller de vestlige hensigter var fjendtlige. Efter den Kolde Krig formåede den vestlige verdensorden nok engang at indoptage en ny bølge af lande - denne gang fra den tidligere kommunistiske verden.

Tre særlige træk ved den vestlige orden har været afgørende for denne succes og sejlivethed.

For det første er den vestlige verdensorden til forskel fra fortidens imperiesystemer bygget op omkring regler og normer om åbne markeder og om ikke at gøre forskel. Det skaber betingelserne for, at fremstormende stater kan fremme deres voksende økonomiske og politiske ambitioner inden for den eksiste- 
rende orden. Op igennem historien har forskellige verdensordner varieret meget med hensyn til, om de materielle goder, der blev genereret, tilflød den ledende stat i uforholdsmæssigt mål eller fordeltes bredt. I det vestlige system er der få forhindringer for økonomisk deltagelse, mens de mulige gevinster er betragtelige. Kina har allerede opdaget de enorme profitter, der kan opnås ved at fungere inden for dette system af åbne markeder.

For det andet er ledelsen af den gældende verdensordnen baseret på en koalition. Tidligere verdensordner har som oftest været styret af en enkelt stat. Parthaverne i den nuværende orden omfatter en koalition af statsmagter arrangeret rundt om USA. Forskellen er vigtig.

Disse førende stater - de fleste af dem højtudviklede frie demokratier - er ikke altid enige, men de indgår i en kontinuerlig forhandlingsproces omkring økonomi, politik og sikkerhed. Magtskifter udspilles typisk mellem to stater, hvoraf en er på vej op, og den anden er en enehersker på vej ned - og den eksisterende orden bryder sammen, så snart magtbalancen tipper.

Men den samlede vægt af de demokratiske og kapitalistiske stater og den resulterende akkumulation af geopolitisk magt tipper i den aktuelle situation balancen i den eksisterende ordens favør.

For det tredje har efterkrigstidens vestlige verdensorden et usædvanligt kompakt, omfattende og bredt anerkendt system af regler og institutioner.

Uagtet den nuværende ordens begrænsninger er den mere åben og regelbaseret end nogen tidligere orden. Staters ukrænkelighed og internationale retsprincipper er ikke bare ord på papir i FN-charteret. De indgår i den grundlæggende måde at fungere på.

Disse normer er naturligvis i konstant udvikling, og USA har selv op gennem tiden været ambivalent omkring at binde sig til internationale love og institutioner - og er det mere nu end nogensinde. Men det overordnede system er fuldt af multilaterale regler og institutioner: globalt såvel som regionalt, økonomisk, politisk og sikkerhedsmæssigt. Disse regler og institutioner udgør et af de største gennembrud i tiden efter Anden Verdenskrig. De har lagt grunden for hidtil uhørte samarbejder og fælles myndighed over et verdensomspændende system.

De incitamenter, som disse træk ved den gældende verdensorden giver Kina for at indgå i den frie verdensorden, forstærkes af verdensøkonomiens ændrede karakter særligt den nye indbyrdes afhængighed, der bliver drevet frem af teknologien.

De mest fremsynede kinesiske ledere har fattet, at globaliseringen har ændret spillets regler, og at Kina derfor har brug for stærke og fremgangsrige partnere rundt om i ver- 
den. Fra et amerikansk perspektiv er en sund kinesisk økonomi afgørende for både USA selv og resten af verden.

Teknologien og revolutioneringen af verdensøkonomien har skabt en logik af økonomiske forbindelser, som er forskellige fra fortidens. Det gør den eksisterende verdensordens politiske og institutionelle logik så meget mere magtfuld.

\section{Nye stormagter}

Den vigtigste fordel ved disse træk i dag er, at de giver den vestlige verdensorden en bemærkelsesværdig evne til at indoptage nye stormagter. Nye medlemmer af systemet har måder at opnå status og myndighed og muligheder for at spille en rolle i ledelsen af verdensordnen.

Det faktum, at USA, Kina og andre stormagter har atomvåben begrænser også en ny stormagts evne til at omstyrte den eksisterende verdensorden. I atomafskrækkelsens tidsalder er krig mellem stormagter gudskelov ikke længere en brugbar mekanik til at skabe historisk forandring. Krigsdrevet forandring er blevet afskaffet som historisk proces.

Den vestlige verdensordens stærke konstruktion af regler og institutioner er allerede begyndt at lette indoptagelsen af kineserne.

Til at begynde med tog Kina alene udvalgte regler og institutioner til sig i forsvarsøjemed. Kina gik ind i regionale og verdensomspændende grupperinger for at beskytte landets suverænitet og økonomiske interesser og på samme tid forsikre andre stater om Kinas fredelige hensigter.

Men som Marc Lanteigne hævder: "Det, der adskiller Kina fra andre stater (og så sandelig fra tidligere verdensmagter) er ikke kun landets opvækst i et miljø af internationale institutioner, der er langt mere udviklede end nogensinde før, men vigtigere endnu at det sker, mens landet gør aktiv brug af disse institutioner til at fremme landets udvikling af en status som verdensmagt."

Kina arbejder kort sagt i stigende grad inden for og ikke uden for den vestlige verdensordens rammer.

Kina er i forvejen permanent medlem af FN's Sikkerhedsråd som en del af arven efter Roosevelts besluttethed på at opbygge denne verdensorganisation med adgang for alle omkring et fælles lederskab bestående af en række stormagter. Det giver Kina samme myndighed og samme fordele ved 'stormagters særstatus' som de andre permanente medlemmer.

Det eksisterende globale handelssystem er også af værdi for Kina, og er det i stadigt stigende grad. Kinas økonomiske interesser er i klar overensstemmelse med det nuværende verdensøkonomiske system, som er åbent og løseligt institutionaliseret, og som Kina begejstret har taget til sig og trives i. Statsmagt er i dag i sidste ende baseret på konstant økonomisk vækst, og Kina er meget vel 
klar over, at ingen større stat kan modernisere sig uden at indgå i det globaliserede kapitalistiske system. Hvis et land vil være en verdensmagt, har det ikke andet valg end at gå med i verdenshandelsorganisationen WTO. Vejen til verdensmagt går vitterlig gennem den vestlige verdensorden og dens multilaterale $ø$ konomiske institutioner.

\section{Brug for beskyttelse}

Kina har ikke alene brug for kontinuerlig adgang til det verdensomspændende kapitalistiske system; landet vil også gerne have den beskyttelse, som systemets regler og institutioner giver.

Eksempelvis giver WTO's multilaterale handelsprincipper og konfliktløsende mekanismer Kina værktøjer til at forsvare sig mod truslerne om forskelsbehandling og protektionisme, som fremstormende økonomiske magter ofte er oppe imod. Udviklingen i Kinas politik tyder på, at de kinesiske ledere er klar over fordelene: Efterhånden som Beijings vilje til økonomisk liberalisering har øget handlen og de udenlandske investeringer i landet, har den kinesiske regering også i stigende omfang taget verdensomspændende handelsregler til sig.

Det er muligt, at i takt med, at Kina tager føringen i verdenshandelsorganisationen, vil støtten til WTO fra de mere udviklede vestlige $\varnothing$ konomier aftage. Men det er mere sandsynligt, at såvel de fremstormende lande som de lande, der er for nedadgående, vil kunne se værdien i de kvasi-juridiske mekanismer, der gør det muligt at løse konflikter eller i det mindste undgå, at de griber om sig.

De eksisterende $ø$ konomiske institutioner med international rækkevidde giver også nye stormagter muligheder for opstigning i deres hierarkier. I Verdensbanken og i den Internationale Valutafond, IMF, er ledelse baseret på økonomiske andele, hvilket lande i vækst kan omsætte $\mathrm{i}$ at have mere at skulle have sagt $i$ institutionerne.

Godt nok har tilpasningsprocessen været langsom: USA og Europa hersker stadig i Valutafonden. Washington har en stemmeandel på 17 procent (sat ned fra 30), hvilket er nok til at afgøre afstemninger, idet der er brug for 85 procent af stemmerne for at skride til handling. $\mathrm{Og}$ den Europæiske Union har afgørende indflydelse på udpegningen af 10 af bestyrelsens i alt 24 medlemmer. Men der er stigende pres i form af især behovet for ressourcer og for at bevare organisationernes relevans, som formentlig vil få de vestlige stater til at lukke Kina ind i inderkredsene af disse økonomiske ledelsesinstitutioner. IMF's nuværende parthavere betragter det eksempelvis som nødvendigt for en fornyelse af institutionen, at de fremstormende udviklingslande spiller en større rolle.

De ser det også som nødvendigt 
for, at valutafonden kan komme igennem sin aktuelle krise omkring, hvad dens formål er. På valutafondens møde i Singapore i september 2006 blev de nuværende parthavere enige om reformer, som vil give Kina, Mexico, Sydkorea og Tyrkiet mere at skulle have sagt. Efterhånden som Kina afvikler sin status som udviklingsland (og dermed som klient hos disse institutioner), vil landet i stigende grad blive i stand til at agere som protektor og parthaver i stedet.

Lederskabet i disse organisationer er ikke kun udtryk for et lands økonomiske størrelse (USA har bevaret sin stemmeandel i IMF til trods for tabet af økonomisk vægt), men et trinvist avancement inden for dem vil ikke desto mindre give Kina betydelige muligheder.

\section{Fredelig forandring}

Set i det lys behøver Kinas fremstormen ikke føre til nogen titanisk kamp med USA om regler og lederskab globalt. Den vestlige verdensorden rummer muligheden for at vende det kommende magtskifte til en fredelig forandring på betingelser, der er fordelagtige for USA. Men det vil kun ske, hvis USA går i gang med at styrke det eksisterende system.

Genopbyggelsen af vestlige regler og institutioner kan synes af liden betydning, nu da Washington er optaget af terrorisme og krig i Mellem- østen. Mange af Bush-regeringens embedsmænd har været direkte fjendtlige over for det multilaterale, regelbaserede system, som USA har formet og ledet.

En sådan fjendtlighed er tåbelig og farefuld. Kina vil få stadigt mere magt: Landet er allerede på vej frem, og USA's stærkeste strategiske våben er evnen til at afgøre, hvilken slags verdensorden, der står klar til at tage imod Kina.

USA er nødt til på ny at investere $\mathrm{i}$ den vestlige verdensorden og befæste de træk ved denne orden, som opmuntrer staterne til at forpligte sig, indpasse og tilpasse sig og udvise beherskelse. Jo mere denne orden binder kapitalistiske demokratiske stater sammen i dybt rodfæstede institutioner; jo mere åben, konsensuspræget og regelbaseret den er; og jo bredere profitten fra den fordeles - jo mere sandsynligt er det, at fremstormende magter kan og vil sikre deres interesser gennem indpasning og tilpasning frem for gennem krig.

Og hvis det vestlige system tilbyder regler og institutioner, der gavner samtlige verdens stater - fremstormende såvel som aftagende magter, svage såvel som stærke, udviklingslande og udviklede lande er verdensordnens dominans så godt som sikret.

Det første, USA må gøre, er at genetablere sig selv som den fremmeste støtte af det verdensomspændende regeringssystem, som 
danner grundlag for den vestlige verdensorden. Gør USA det, vil det først og fremmest lette den form for kollektiv problemløsning, som er til alles fordel. Samtidig vil USA's magt blive mere legitim, når andre lande ser den blive brugt til at styrke eksisterende regler og institutioner.

USA's magt vil blive styrket derved. Lande i Vesten vil blive mere tilbøjelige til at arbejde sammen med den amerikanske myndighed frem for at bekæmpe den.

Dette vil styrke Vestens egen centrale position og herredømme.

En fornyelse af vestlige regler og institutioner forudsætter bl.a. en opdatering af de gamle handler, som lå til grund for afgørende sikkerhedsaftaler i efterkrigstiden. Den strategiske forståelse bagved både NATO og Washingtons østasiatiske alliancer er, at USA vil samarbejde med sine allierede om at sikre sikkerheden og tillige inddrage dem i beslutninger om magtanvendelse - og at USA's allierede til gengæld vil fungere inden for den amerikansk ledede vestlige orden.

Sikkerhedssamarbejde i Vesten er fortsat udbredt; men nu, da de største sikkerhedstrusler er mindre tydelige end under den Kolde Krig, står disse alliancers formål og ansvar til diskussion. Tilsvarende er USA nødt til at genbekræfte alliancernes politiske værdi og anerkende, at de indgår i en bredere institutionel konstruktion i Vesten, som gør det muligt for stater at indgå forretninger med hinanden.

\section{Behov for åbenhed}

USA bør også forny sin støtte til de omfattende multilaterale institutioner.

På den økonomiske front vil det bl.a. sige at bygge på WTO-aftaler og verdenshandelsorganisationens konstruktion, herunder at bestræbe sig på at få afsluttet den igangværende Doha-rundes forhandlinger om handel, som stræber efter at udvide markedsmulighederne og liberalisering af handlen til også at omfatte udviklingslandene.

WTO befinder sig i en kritisk fase. Den grundlæggende norm om ikke at forskelsbehandle er under pres fra de mange bilaterale og regionale handelsaftaler. Samtidig er der stigende tvivl om, hvorvidt WHO faktisk kan gennemføre en liberalisering af handlen i særligt landbrugssektoren, som er der, hvor den kommer udviklingslandene til gode.

Disse problemstillinger kan synes af begrænset betydning, men det drejer sig om den frie verdensordens grundlæggende natur: dens forpligtelse på almengyldige regler om åbenhed og spredning af gevinsterne. Lignende tvivl hjemsøger en række andre multilaterale aftaler om bl.a. global opvarmning og ikkespredning af atomteknologi - og kræver således også fornyet amerikansk lederskab.

Strategien her er ikke blot at sik$r e$, at den vestlige verdensorden er 
åben og regelbaseret. Strategien må også gå ud på at sikre, at denne orden ikke fragmenteres i en række bilaterale og minilaterale pagter. For sker det, vil verden brække over i konkurrerende sfærer: en amerikansk og en kinesisk. I jo højere grad de sikkerhedsmæssige og økonomiske forbindelser er multilaterale og omfatter alle, jo bedre vil det globale system fortsat hænge sammen.

I tillæg til at bevare verdensordnens åbenhed og holdbarhed er USA nødt til at øge sine bestræbelser på at integrere de fremstormende udviklingslande i globale nøgleinstitutioner. At tage fremspirende lande med i regeringen af den internationale orden vil give den nyt liv. USA og Europa må finde plads ved bordet ikke kun til Kina, men også til lande som Brasilien, Indien og Sydafrika.

En rapport fra Goldman Sachs om de såkaldte BRIK-lande (Brasilien, Rusland, Indien og Kina) bemærkede, at i 2050 kan disse landes økonomier sammenlagt være større end de oprindelige G6-landes til sammen (Tyskland, Frankrig, Italien, Japan, Storbritannien og USA).

Hver enkelt international institution frembyder sine egne udfordringer. FN's Sikkerhedsråd er måske den sværeste at håndtere, men reformeringen af denne institution vil også give de største gevinster. Mindre formelle instanser som de såkaldte G20 og forskellige andre net- værk regeringer imellem kan fungere som alternative måder at give andre lande stemme og repræsentation.

\section{Den frie verdensordens sejr}

Det helt centrale, som amerikanske ledere skal lægge sig på sinde, er, at Kina måske vil kunne overhale USA, hvis USA står alene, men at det er langt mindre sandsynligt, at Kina nogensinde vil formå at overhale den vestlige verdensorden.

Hvad økonomisk vægt eksempelvis angår, vil Kina passere USA som den største stat i verdenssystemet omkring år 2020. (Grundet sin store befolkning har Kina kun brug for en produktivitet på en femtedel af USA's for at blive verdens største økonomi).

Men når man betragter det vestlige systems økonomiske ydeevne under ét, fremstår Kinas økonomiske fremskridt langt mindre betydelige. Den kinesiske økonomi vil langt ud i fremtiden være meget mindre end de samlede økonomier i OECD - organisationen for økonomisk samarbejde og udvikling i demokratiske lande med markedsøkonomi.

Det gælder i endnu højere grad den militære styrke: Kina kan ikke håbe på at komme op i nærheden af OECD's totale militærudgifter i nogen nær fremtid. Den kapitalistiske og demokratiske verden er en magtfaktor til fordel for bevarelsen og udvidelsen af den bestående ver- 
densorden. Hvis Kina vil udfordre denne verdensorden fra en fremtidig magtposition, har landet en langt større opgave foran sig, end hvis landet blot står over for USA.

USA's 'unipolære stund' vil en dag være forbi. Det amerikanske herredømme vil en dag tage en ende. USA's overordnede strategi bør derfor være et svar på det helt centrale spørgsmål om, hvilken verdensorden USA ønsker at have på plads den dag, landet selv er mindre magtfuldt?

Det kan man kalde Rawls' problematik iklædt nutidige gevandter. Den politiske filosof John Rawls mente, at politiske institutioner bør undfanges bag et 'uvidenhedens slør'. Det betyder, at bygherrerne skal forme institutionerne, som om de ikke var klar over, hvor de selv ville befinde sig i det socioøkonomiske system. Resultatet ville være et system, som sikrer en persons interesser, hvad enten han er rig eller fattig, stærk eller svag. USA er nødt til at have denne tilgang til sit lederskab af nutidens verdensorden.

USA må tilrettelægge institutioner og befæste regler, som vil sikre landets interesser uafhængigt af, nøjagtig hvor i hierarkiet det vil befinde sig, og præcis hvordan magten vil være fordelt om 10, $50 \mathrm{og} 100$ år.

Heldigvis er en sådan orden allerede på plads. Opgaven nu er at gøre den så omfattende og så institutionaliseret, at Kina ikke har andet valg end at blive et fuldgyldigt medlem af den.

USA kan ikke forpurre Kinas entré på verdensscenen, men USA kan bidrage til en sikring af, at Kinas magt udøves inden for rammerne af de regler og institutioner, som USA og landets partnere har udtænkt i løbet af det sidste århundrede. Regler og institutioner, som kan beskytte alle staters interesser i fremtidens mere overfyldte verden.

USA's position i verden er måske nok ved at svækkes - men det internationale system, som USA leder, kan meget vel vedblive med at være det 21. århundredes herskende orden.

\section{G. John Ikenberry er professor $i$ stats-} kundskab ved Princeton University og har skrevet bogen 'After Victory: Institutions, Strategic Restraint, and the Rebuilding of Order After Major Wars'. Trykt med tilladelse fra Foreign Affairs, der bragte artiklen i januar/februarnummeret 2008 (volume 87, nr. 1). 